On the Shock of Civil War: Cultural Trauma and National Identity in Finland and Ireland.

\author{
Bill Kissane, \\ Department of Government, \\ London School of Economics
}

I question whether any serious civil war ever does end.

T.S. Eliot 1947.

Civil war divides the nation. Those who pose the question of how society recovers afterwards consider the challenges as those of reconstruction and reconciliation. There is less work on the role of national identity in these processes. Is re-integration of the losers possible on the basis of an existing national identity, or does a new identity have to be found? If the former, what has to change to make that original identity more inclusive of both sides? Much depends on narratives of conflict. I explain why the Finnish civil war of 1918 has become a unifying 'cultural 
trauma' for the Finns, whereas the Irish civil war of 1922-23 never became the dominant referent in terms of national identity. The difference is explained by the greater shock civil war posed to Finnish national identity.

National Identity and the societal meaning of civil war.

General books on civil war usually begin with two observations: civil wars are increasingly common and they are especially destructive. The associations with chaos go back to ancient Greece (González Calleja 2013: 13-14), the Romans lamented their recurrent nature (Armitage 2017: 69), while civil war has long been the 'counter-concept' to the more progressive idea of revolution (Kissane 2016: 4). Civil war is a subject with an ancient past and a very violent recent history.

Given the generality of the phenomenon, it is not surprising that the literature on its consequences should be quantitative. One question is how civil wars impact on economic development (Collier et al 2003). Their effects on public health is another 
(Ghobarah, Huth, and Russett 2003). The stipulation for a minimum threshold- usually a thousand deaths - in the very definition of civil war, suggests that the amount of violence is a reliable guide to their destructiveness.

One effect of this empirical rigour is a neglect of 'societal meaning': the significance of a conflict in a country's history, in the broader historical and sociological context in which it occurred, or in a larger cycle of conflicts (Newman 2015: 9). For Newman investigating societal meaning requires 'an appreciation of different historical and social contexts'. 'As an expression of modernity' (ibid: 3), contemporary conflicts have much to do with the consolidation, contestation, and disintegration of state authority across the world. Hence his solution to the question of societal meaning reflects the central role of the state in politics and the importance of state-society relations.

Yet nationhood also matters. One could tell the story of the Second World War as one of geo-political ambitions, battlefields and resources. This misses the fact that in many 
countries defeat in war created 'an existential crisis of national sovereignty', revealing the 'deep fractures that lay beneath the surface of unity'. The collapse of state authority posed questions about the meaning of the nation, a paradigm of unity dramatically problematized by internal fractures that were 'simultaneously' murderous and pregnant with future political possibility' (Mazower 2013: 2). Consider the fighting between fascists and partisans in Northern Italy. Both sides felt they represented the whole of Italy and accused the other side of dragging the nation into fratricidal struggle (Pavoni 2013: 271).

Nationalism scholars (Centeno 2002; Hall and Malešević 2013; Hutchinson 2017), have shown that warfare has had a transformative effect on both state and nation. They do not engage with civil war specifically. There are criteria which differentiate civil from inter-state war. The conflict must be internal. Civil war is above all a crisis of domestic social relations. And when the enemy is internal, the polarisation is especially traumatic. Finally, the challenge of reconciliation is much greater 
after civil war, since the armies cannot retreat behind their borders. As the Roman historian Lucan wrote, it is the wounds left by the hands of a neighbour that will not be forgotten (Kissane 2016: 215).

Hence one criterion for judging a conflict to be a civil war is that the protagonists should have to face the prospect of having to live together in the future (Licklider 1995). This prospect involves questions about the meaning of the nation. Civil war constitutes a trauma for members of a society that want, despite their differences, to live together in one nation. In Finland and Ireland specifically, the occurrence of civil war at the precise moment of state formation made this issue acute. Both wars had the capacity to bolster national identity but also raised questions about the grounds on which the collectivity rested (Eyerman 2012: 4).

The subsequent importance of the civil war to Finnish national identity was bound up with Finland's geo-political vulnerability vis a vis Russia. This vulnerability, acute up to 1944, made 
the re-integration of the losers imperative. In such a context the nation should be seen not as a dominant discourse or a composite of discrete traditions, but as an underlying 'code' of meanings pertaining primarily to issues of unity and disunity (Alapuro 2002: 172). In Ireland, there was cultural vulnerability vis a vis Britain, but no lasting threat of re-occupation (Cambell and Hall 2017: 71). The nation's putative Catholic and Gaelic roots were not at issue in the civil war, but the political question of how to achieve full independence - by force or by constitutional methods - was. The civil war helped re-establish the centrality of this cleavage and the organisation of the party system around the civil war parties kept it so (Hutchinson 2005: 108).

In Ireland, where the civil war was Green Against Green (Hopkinson 1988) the criteria for membership in the nation and national unity was restored on the basis of shared cultural values. In Finland, where the shock of civil war was much greater, coming to terms with the past involved a cultural process of re-evaluation which extended into the 1960s and later. There was a need to 
narrate the events of 1918 in a new way. A recent current in cultural sociology considers trauma, and the nation as connected primarily with narration. Trauma does not emerge naturally: painful experiences must be translated into a narrative frame. In Finland this narrative frame ultimately took the form of a collective trauma. 'Cultural trauma' is a discursive process when the emotions that are triggered by a traumatic occurrence are worked through, and an attempt is made to heal this collective wound (ibid, 8). This 'working through' has happened in Finland and the result (unlike in Ireland) was that the societal meaning of the civil war became part of the national narrative.

\section{The civil wars}

It is Tilly's (1975: 46) observation that the later a state has become part of the European state system, the more likely it is to have been formed as a consequence of wars between the older European states, or from negotiations ending those wars. The Finnish civil war of 1918 followed the Bolshevik Revolution of October 1917, the 
Irish civil war the Anglo-Irish Treaty of December 1921. The Finnish conflict lasted from 27 January to 15 May 1918. Ireland's lasted from June 281922 to April 241923.

Finland had become a Grand Duchy of the Russian Tsar in 1809. It gradually built on this autonomy; and by 1914 a common national identity, economy and multi-party system had emerged. The Grand Duchy allowed Finnish and Swedish speakers found common ground. In 1892 Finnish was made a national language alongside Swedish. Finland's Diet had been reconvened in 1867, and following the 1905 Revolution, the Eduskunta, a parliament elected on universal adult suffrage, was established. The Social Democrats were the largest party from 1907 up to 1917.

Ireland was incorporated into the United Kingdom in 1801. Movements demanding religious equality, political autonomy and land reform followed. The dominant mode of opposition was constitutionalist: the 'Home Rule' parties wanted a native parliament restored to Dublin, not absolute independence. Most Irish Protestants, concentrated in the North-East, opposed Home Rule. At the same 
time, land reforms were establishing a Catholic proprietorship. The main cleavage among nationalists was political: whether to trust in parliamentary methods or in physical force. After a failed rising in Dublin during Easter 1916 the second (republican) tradition became dominant.

There are many parallels between their histories in the late nineteenth century (McMahon and Newby: 2017). A Finnish national identity was promoted by the Fennomans since the $1860 s_{L}$ and a variety of educational, labor, religious and temperance movements had tried to raise Finnish national consciousness. The intention was to strengthen loyalty to the Grand Duchy, and the Finnish-speaking smallholder was idealized as the model citizen. In Ireland, since the 1890s, the Gaelic Revival had tried to shift the focus away from Westminster politics and onto the historic Irish community which had allegedly enjoyed a golden age before the arrival of British rule (Hutchinson 1987). Hence in both countries cultural nationalists built up a positive image of the population, to be shattered by civil wars 
whose destructiveness was blamed on the character of 'the people' (Hämäläinen 1979; O’ Callaghan 1984).

The First World War had led to growing radicalization. Neither country was a theatre of war, but British and Russian troops were stationed on their respective territories. The War averted a conflict between Catholics and Protestants over Home Rule. The 1916 rising, the proclamation of the Republic, and the execution of fifteen leaders, transformed the conflict into one between the British state and Irish republicanism. Constitutionalism became discredited. After its 1918 general election victory, Sinn Féin demanded that Britain recognize an Irish Republic. The Irish Republican Army (IRA) also began a war of independence in January 1919 which continued until July 1921. Opposition was strong only where Unionists were in the majority. Partition in 1920 placated them.

Only after 1899 did Russification policies disturb the tradition of Finnish accommodating Russian interests. The Eduskunta, was repeatedly dissolved, and no parliament had the authority to pass reforms demanded by the Left. With food shortages, land evictions, 
and unemployment, the Socialist movement radicalized. Reflecting the problem of rural poverty, about 14,000 evictions took place between 1909 and 1915 (Peltonen 1995: 31-32). Yet the Social Democrats could not use their parliamentary majority to effect reform, and its leadership was losing control of the workers' movement. The Social Democrats and the bourgeois parties became divided over the former's 'Power Law', making Finland politically independent, but leaving foreign policy to the Russians. The Provisional Government ordered fresh elections in October 1917, in which the Social Democrats lost their majority. The new bourgeois Senate declared independence on 6 December 1917, and proceeded to assert its authority over Russian troops in Ostrobothnia. The Germans intervened on the White side in the civil war, which began on 27 January 1918.

Sinn Fein's victory in elections in 1921 reinforced its claim to the whole island. Yet it soon became divided between those for whom the Anglo-Irish Treaty signed on December 61921 was a sell-out, and those for whom it was 'a stepping stone' to independence. This Treaty gave 26 counties internal autonomy, but the 'anti-treatyites' objected 
to the continuance of partition and the oath to the British Crown required of parliamentarians. The election on 16 June 1922 saw these Republicans lose their majority, and the Irish Provisional Government now claimed a mandate to implement the Treaty. The anti-treatyites rejected majority rule as a basis for adjudicating the Treaty issue, knowing that the majority would chose compromise.

The Irish Provisional Government's decision to attack the IRA on 28 June 1922 followed an ultimatum delivered by the British government two days previously. The defeat of the IRA in Dublin enabled the Provisional Government to project its authority, labelling the IRA 'irregulars'. With a constant supply of arms from Britain, the National Army grew to over 50,000 men, and achieved a rapid victory in the war's conventional phase. The Catholic Church strongly backed the government. Guerrilla resistance continued into April 1923, but reprisal executions and weak public support demoralized the IRA, which declared a cease-fire on 24 April 1923.

The Finnish civil war was more conventional, with the reds (punaiset) first controlling the more urbanized south-west. The 
Bolsheviks supported them mainly through arms supplies. The white (valkoiset) counter-offensive in early March, supported by the German Army, was successful. White victories in the battles of Tampere and Viipuri, and German occupation of Helsinki ensured victory. Atrocities were common, but since most lost their lives in prison camps through cold, hunger, and executions - the reds suffered most. Memories of the red and white terrors lingered long. After its victory the Finnish senate decided to appoint a German crown prince as monarch in 1918. The German defeat however, meant that Finland became a republic - in 1919.

\section{The shock of civil war}

For social change to be traumatic, Sztompka (2000: 452) argues that it must, firstly, have a temporal quality: the change must be sudden and rapid. The Finnish and Irish civil wars followed rapid changes in power relations between different strands of their nationalist movements, which meant that the nation suddenly became a zone, not just of conflict, but of civil war. The Finnish conflict began less than two months after Finnish independence 
was declared. In Ireland just seven months elapsed between the signing of the Treaty and the civil war.

Secondly, social change must have a particular substance and scope: being radical, deep comprehensive; touching the core of society. In both countries, divisions had emerged over who could further the nation's interests but in Finland these divisions had profound social dimensions. The victors interpreted their civil war in national terms, as 'a war of liberation' (Vappausota) against leftist forces contaminated by their exposure to the Soviet Union. The left, in contrast, interpreted the war in social terms, as a defence of the gains for the Social Democrats which had followed the October Revolution (ibid: 169). In Ireland the losers interpreted the civil war in national terms, as a continuation of the war of independence. The pro-treatyites saw the conflict in social terms, as a defence of majority rule and the property order (Kissane 2005: 239). Yet because the process achieving full independence for the island was incomplete (and seen as unfinished business) the former interpretation prevailed. The names 'Free Staters' versus 'Republicans' - compared 
to 'Reds' versus 'Whites' - reflect the stronger social basis of the Finnish conflict.

Thirdly, the change must have specific origins: it is perceived as imposed, exogenous, coming from the outside. White Finns claimed the socialist movement had been contaminated by their exposure to Bolshevik Russia. They considered the 'Reds' 'those who had lost their fatherland'. The Irish conflict also came 'from the outside in' and the defeated side had to face the fact that their 'nation' seemed to have been defeated at the moment it was born. The Free State, they argued, was not Irish, not free, but a puppet of British policy. Such divisions revealed 'The Madness Within' (the title of a civil war documentary by RTE, the state broadcaster).

Finally, the change is encountered with a particular mental force: it is perceived as unexpected, unpredicted, shocking, and repulsive. Since 1809 Finland had been a peaceful part of the Tsarist Empire. Nonetheless, the civil war produced casualty rates comparable in per capita terms to the Spanish civil war (1936-39). Far more died as a result of executions $(11,500)$ or from prison 
camp conditions $(13,500)$ than were killed in battle $(8,700$ deaths $)$ (Alapuro 2014: 22). The casualties of the Irish civil war in 1922-23, less than 1500, were small in comparison. The IRA avoided conventional fighting and many of its members did not take part in the guerilla war which began in August 1922.

In the language of medicine trauma refers to the impact of a sudden event on the body, leaving it less functional than before in some crucial respect. The Finnish and Irish conflicts occurred at a particular moment in their historical development, almost immediately after independence. Since deep internal divisions emerged the moment legislative independence had been achieved, this timing made for trauma of a specific kind. The naturalistic approach to trauma is of events that befall actors, which because of their suddenness and brute force radically overstrain their capability to respond (Joas 2005: 367).

Homogeneity had long been regarded as a positive societal trait which made these wars harder to comprehend. Finnish and Irish nationalists did not always value particular interests as the 
basis of political identity, but in 1918 and 1922 different actors had different views of a general common interest. The problem was that views of this general interest could differ in a way that made any negotiation between them difficult (Kettunen 2004: 293). The struggle over who had the right interpretation of 'the people' gave the Finnish conflict a particular bitterness (Liikanen 1995). And the word for people in Finnish (kansa) was also the word for nation. The Irish civil war was fought between two wings of Sinn Féin and the IRA, both defending the rights of 'the nation' and both claiming to be representing the people's will.

Yet homogeneity continued to be the basis for nationbuilding, and rapid political reconstruction followed the civil wars. Ethnic markers - language in Finland, religion in Ireland - pointed to larger national identities, distinct from Russia or Britain which each side could share in. Their formative experiences remained a source of trauma, but shared identity (combined with their vulnerability as small states) encouraged the political accommodation of the losers. 


\section{The Political Accommodation of the Losers.}

Both civil wars found their conclusion in amnesties that left questions of innocence and guilt aside. The first step on the road to national reconciliation was not forgiveness, but the hope that, under the common roof of institutions, relationships could heal on their own (Schlink 2010: 88). The roof was provided by Dáil Éireann and the Eduskunta, parliaments which were symbols of pre-war unity. The aim was to heal damaged relationships through 'institutionalized encounters' which made coexistence possible (ibid: 2010).

Civil wars demand the forcible establishment of unity, and there can usually be only one dominant authority above the clashing interests (Bracher 1985: 113). Yet Finland and Ireland continued with pluralism, which allowed the losers back into the system. In Finland in 1918 an amnesty was passed for those with shorter sentences, and further amnesties, also supported by the Social Democrats, followed in 1921 and 1923. The Social Democrats pursued a policy of 'class peace' and worked for the consolidation of representative institutions. 
Such was their electoral strength that in 1919 they again became the largest party in parliament, and controlled 160 localities (Haapala 2008: 2). They were led by men like Väinő Tanner who had not supported the revolutionary attempt in 1917-18.

Yet this comeback was seen by some as proof of the effete character of democracy. The quasi-fascist 'Lapuas', which emerged in 1929, saw themselves as making a valiant attempt to safeguard the achievements of the civil war and restore the white Finland that had emerged from it' (Nevakivi, Jussila and Hentilä 1999: 155). They were first successful in collapsing the government. Fortunately, the victory of the conservative Svinhufvud at the 1931 presidential election led to the assertion of the rule of law the following year. Alapuro (2002: 174) argues that the Scandinavian social structure, with a free peasantry placing limits on the exclusion of working people, was the critical reason why the system did not shift to the right. The Agrarian Party had no sympathy for efforts to extend the repression to the Social Democrats. After it won a presidential election in 1937, the Social Democrats entered into a coalition with them, based on the 
protection of democracy and resistance to Fascism. This coalition between former adversaries stabilized politics (Karvonen 2000: 150$51)$.

The Irish Civil War concluded with mass internment and reprisal executions. The oath of allegiance was required of parliamentarians until 1933. However, the 1920s also saw the assertion of civilian authority during 'the army mutiny' of 1924, the 'civilianization' of the security apparatus, and the demobilization of most of the National Army (O' Halpin 1999: 39-81). A general amnesty was declared in November 1924. In 1926 anti-treaty Sinn Féin split between those willing to take the oath and enter the Dáil, becoming Fíanna Fáil, and those remaining outside. Labour supported a minority Fíanna Fáil government in 1932. Fíanna Fáil's leader, Éamon de Valera, had declared the nation's most urgent need to be 'internal peace', but he also wanted to use the institutions of the Free State to achieve what they had lost in the civil war. Positive measures included the abolition of the oath in 1933 
and a new constitution in 1937, but his government still proscribed the IRA in 1936.

After a civil war those responsible for state-building have to consider what the building-blocks of the nation were. Alapuro (1988: 205) contrasts two strategies of integration, one based on an inter-class cultural-nationalist community, and the other on national integration through conciliation. The first approach implied the suppression of class differences, and the Finnish Socialist Labour Party, formed after the Civil War, was banned after having contested the 1922 election. It contested the 1924, 1927 and 1929 elections as the Workers and Smallholders Party, but was banned again after 1929. The second, conciliatory, approach was espoused by the Agrarian Union and the National Progressives, and prompted the passing of land reform bills and amnesties for the rank-and-file Reds.

Ireland, where both sides drew heavily on the pre-1914 traditions of cultural nationalism, saw the reconstruction of the nation as an inter-class cultural community. The winners' Cumann $\mathrm{Na}$ nGaedheal, governed until 1932, when Fíanna Fáil replaced it for 
sixteen years. Both parties had their origins in Sinn Féin. Political parties had been enormously important before independence because of the antagonism between the largely unionist holders of state power, and those nationalists that organized mass opinion (Garvin 1981: 183). Fíanna Fáil continued the nineteenth-century pattern of standing up to Britain, but both the civil war parties furthered the pattern of establishing mass centralized organizations which cut across class and territorial cleavages (ibid: 216).

Finland also benefited from the integrative power of party politics. The Red Green compromise in 1937 strengthened the sense that internal class differences were legitimate and pointed to Nordic Social Democracy. Critiquing the application of a conflict model to the whole of its interwar politics, Tepora (2014) argues that the first public acts of reconciliation in Finland actually took place in the late 1930s, and were favoured by the Social Democrats. Yet up to 1944 'White Finland', while maintaining a parliamentary form of government, employed repressive legislation to drive the communists underground. Its institutional symbol was the Civic 
Guard, a paramilitary organisation which existed alongside the regular army, with as many as 100,000 members (Nevakivi, Jussila and Hentilä 1999: 144). In the Winter War (November 1939-March 1940) and the Continuation War (June 1941-September 1944) Finland fought the Soviet Union, becoming the only former territory of the Tsar's to keep its independence in the twentieth century.

The Finns thus faced the specific challenge of accommodating the losers at a time the Soviet Union was a threat to Finland's survival. The Communists, with their ties to Moscow, were culturally marginalized and could not operate openly until after 1944 when their party was legalized. World War Two gave the Finnish left a chance to demonstrate its patriotism, an opportunity which it took. United in the winter and Continuation Wars, Finland began the integration of the Communists that year. The army and the White Guards had been divided over whether the threat came from within (the radical left) of from without (Soviet Russia). That the White Guards were made illegal the same year as the Communists were legalised suggests that the second interpretation prevailed. 
In Ireland the integrative power of Irish nationalism was much stronger. After the civil war the society became dependent on strong centralised organisations (the Catholic Church, the Gaelic Athletic Association, and the Gaelic League) for the supply or moral and social cohesion. These bodies were means of rapid societal re-integration and advocates of values both civil war sides supported. In contrast to the Finnish communists, the unreconciled Irish republicans in Sinn Féin and the IRA did not become a dissident society, but only 'a dissenting current within Irish society' (Bowyer Bell 1972: 224). They remained committed to a 32-county republic, but were not isolated socially or culturally.

Indeed a very traditional consensus returned. The 1937 constitution made explicit many of the values of Catholic social teaching that Cumann na nGaedheal had legislated for in office. The 1938 Anglo-Irish Trade Agreement heralded a joint commitment to an Irish economy consisting of a protected industrial sector combined with a dominant cattle-exporting agriculture, closely linked to Britain (Daly 1992: 94). Fine Gael's support for Fíanna Fáil's 1939 
Offences against the State Act, aimed at the IRA, was another sign of consensus. The powerful Catholic Church propagated the idea of the nation as an inter-class community.

Both countries' vulnerability as two small nations had encouraged political compromise. The difference was that the Irish division was accommodated into a nationalist paradigm. Ankersmit (2002: 193-213) distinguishes between 'consensus', presupposing a commitment to a predefined value system, and compromise based on the mutual recognition of the particular nature of the interests in question. In Finland consensus - on independence, democracy, and general social reform - had been destroyed. Only compromise could produce stability. In contrast, the Irish civil war division was primarily political and consensus was easier to re-establish. The idea of the nation as an inter-class community meant that internal differences -with Protestants and with Irish Labour - were downplayed. The state remained neutral in the Second World War, a policy supported by both civil war parties. 
Both cases are good candidates for a state-centric approach to reconstruction. Wimmer's (2012) work on the transition from Empire suggests that fresh rules of the game usually emerge in the new nation states which govern the treatment of minorities. The relative success of Finland and Ireland was that the defeated minorities were enabled by such rules to govern. Yet culturally, each side should also be able to commemorate their causes in such a way that a divided society becomes a community of fellow citizens (Hutchinson 2017: 74-75). The commemoration of the Irish state's victory was mute compared to that of the losers (Dolan 2003). The republicans had a richer and more powerful tradition of commemoration and after the 1932 election Fianna Fáil remained the dominant party until 2011. In Finland by the 1930s more than 350 towns had erected monuments commemorating the fallen whites; there were only five official memorials in honour of the reds (Peltonen 2002: 192). There was a greater need for cultural repair than in Ireland, where the losers's had the cause of revolutionary nationalism on their side. 
Indeed Finland will provide an illustrative example of how a civil war can lead to a cultural trauma. With its massive violence the conflict had delivered a great shock to the Finns' sense of themselves so there was a greater need to 'work through' the conflict culturally. In terms of national identity the civil war would also become 'a dominant referent', a new meaning structure against which other events are measured. This conflict' had an exceptional status in the context of Finnish history and fits Eyerman's $(2001,2)$ argument that cultural trauma is a discursive response to a tear in the social fabric, where the foundations of an established collective identity are shaken by a traumatic occurrence, and are left in need of re-narration or repair.

\section{Narration and cultural repair.}

Post-conflict reconciliation requires the creation of a common selfimage. Finnish and Irish cultural nationalists had long idealised the peasantry, promoted language revival and the clergy supported the new states. There was cultural material for nation- 
builders to work with. When it came to responses to civil war however, political reconstruction proved sufficient in Ireland: there was no visible 'coming to terms with the past'. In Finland a cultural process was necessary before the left could be integrated in a positive way. While the political accommodation of the losers occurred quickly, cultural and social reconciliation took more than half a century (Alapuro 2014). The societal meaning of 1918 had to be brought into the national narrative.

The Finnish civil war had come 'from the outside in', but was first incorporated into national political traditions by being regarded as a war of liberation. The victorious whites promoted the Civil War as a 'freedom war' (Vapaussota), preventing the incorporation of Finland into Bolshevik Russia. Their view was that the violence had been necessary in 1918 to complete the process of gaining independence. This independence had come about only as a consequence of the First World War, and the whites believed that nation-building was incomplete in 1917. The roots of independence were thought of as originating deep in the past, and the white 
victory the culmination of a long-term development (Haapala 2008).

This narrative deepened the divide with the left, since it suggested they were Finns 'who had lost their Fatherland'.

The absence of transitional justice made narratives important. If the dominant narratives about civil war are wrong, the relations between the actors have not been repaired. In cases where one side has won, reconciliation is usually about revising such dominant narratives and producing narratives that address the complexity of conflict, stories which acknowledge the suffering of all sides. Váinő Linna's trilogy of novels, Under the Northern Star (1959-1962), gave a sympathetic account of the Reds for the first time by stressing their social grievances. Half a century after the civil war Linna's trilogy helped integrate the Reds into the Finns' sense of themselves. Only in the 1960s did Finnish historians begin to study the civil war objectively. It was then that historians uncovered the full scale of the white terror, and its organizational basis. Even if the last step on the road to reconciliation, public acknowledgement of the Left's perspective allowed healing (Forsberg 2009). 
For the 'cultural trauma' school meaning is not inherent in what happens; trauma, like all forms of memory, is a matter of appropriation, negotiation, of cultural struggle (Sundholm 2011). The point of the approach is not to deny that events matter, but to recognise that there is selectivity at work in how people respond to events. One factor that promoted fresh thinking in Finland was that the society was very divided on class lines, but needed to maintain unity in the face of Soviet pressure. Friendly relations with the Soviet Union became official policy from 1944 on. And a change in the conception of democracy, to include social democracy took place after the war.

Indeed we can see these cultural changes - which took the political re-integration of the left in the 1930s a step further - as examples of 'civil repair', a process driven by carrier groups which engaged the conscience of the wider society (Eyerman 2001: 3). Wood and Debs (2013: 611) suggest that such narratives of suffering can transform a group's larger identity. Their effect on national identity stems from their success in having an event 
acknowledged as a trauma, and becoming the exceptional event. If a trauma resonates with the wider group it becomes integrated into the collective identity.

Writing of the Slovak and Czech intelligentsia after communism Eyal (2004: 7-8) outlines two social roles for intellectuals. The former mainly saw their role as one of maintaining collective identity and promoted the idea of the nation moving through time without fundamental change. This was true of the conception of the Finnish civil war as a war of liberation. A very different 'will to memory' existed among Czech intellectuals who saw their role as one of overcoming trauma and the dislocation and suffering it had brought. The first role embeds intellectuals in society as the guardians of collective memory and ethnicity; the second makes them pastors of individual memory and conscience (ibid: 12). The Finnish state has embraced the second approach. Its currrent project 'War Victims in Finland 1914-1922' tries to gauge, as accurately as possible, the number of people who were killed or executed in the civil war. The results, available on the national archive website, suggest 
that the state now sees detailed historical research as a way of dealing with a national trauma (Mirkkala 2012: 246).

The Irish civil war was also traumatic for those that had invested so much hope in independence. Partition, which preceded the civil war in 1920, was cemented by the Boundary Commission in 1925. In a context of disillusionment with the fruits of independence, Flanagan (2015: 9) sees 'a competitive dynamic' between two sides that shared Catholic and militarist values. The Pro-Treaty cause has been justified in terms of their contribution to state-building, their defence of democracy, or the eventual triumph of the 'stepping stone' approach to (Southern) Irish Independence (Curran 1986; Younger 1965; Garvin 1996). The anti-treaty perspective located the conflict in an ongoing revolutionary process. Indeed in Ireland it was the losers who believed that violence had been necessary to protect independence in 1922. Dorothy MacArdle's (1937) best-selling The Irish Republic represented the republican defeat as an interruption of a revolution. Later republican historians (Gallagher 1965; Greaves 
1971) developed her view that the civil war was not something new, but a continuation of a longer-term revolution.

This approach has made it difficult to establish a societal meaning for what happened in 1922-23. The labour agitation, sectarian violence in Belfast, agrarian unrest, the burning of more than one hundred and ninety mansions and country homes (many Protestant-owned) (Clark 2014), and the changed role of women did not find their way into history until recently. The small and marginalised Irish left had little influence. On the one hand, the competition over the past strengthened national identity since the two parties had their roots in Sinn Féin. Yet it marginalised the experiences of those for whom the nationalist revolution was not primary, or of those for whom it was regrettable. It was Hopkinson's 1988 Green against Green that boosted the empirical study of the war's complexity, particularly in terms of the spur to local history. Some recent historians (Foster 2014; Kostick 1996) have applied class analysis to the conflict. 
On both sides of the Irish split the initial narration of events, locating them in centuries of resistance to British rule was also underpinned by 'a powerfully teleological concept of time' (Flanagan 2015: 9). The experience was 'transmissible' (Benjamin 1999: 97): the conflict could be integrated into a historical continuum linking the generations and consolidating the feeling of a common culture. Since one consequence of violent conflict is to destroy this sense of temporal flow, this teleological approach made potentially disorientating events familiar. Bollas (2015: 169-181) has argued that after a psychotic episode it is important for a patient to return to her 'narrative core'. His argument is that talking about the past soon after a mental breakdown can help reverse the schizophrenic process because it implicitly restores the narrative hegemony of the I. As both patient and therapist go over the details of the recent past, 'this act of historicity and narrativity becomes the glue that restores the self and prevents further splitting and fragmentation' (ibid: 171). The Irish quickly returned to their narrative core and the result was that the experience of internal 
division became submerged in a larger story of constant struggle against British rule.

Being more of a rupture, the Finnish conflict could not be successfully restored in narrative or epic form, leaving those who suffered most abandoned to themselves. The white narrative had invalidated the suffering of the left, who had no access to the emotions they experienced in 1918. Cut off from public memory before the 1960s, this made the work of cultural repair more important. Decades of cultural exclusion had deepened the wounds of civil war and made the task of cultural repair more important. Bolas argues that a person in therapy who is not encouraged to historicise his past, may be revived by medication, 'but he will not be the person one could have reached before this selfabandonment and fragmentation' (ibid: 171).

Cultural sociology is a useful tool for comparing these processes, highlighting the importance of narration and temporality in Ireland, and showing that the exploration of societal meaning can become part of coming to terms with a civil war. Because 
Finland was a class-based society, the political accommodation of the left eventually led to a public re-evaluation of the civil war. Ireland did not see a strong challenge from the left, and the Catholic basis of the inter-class community made for a different approach to internal divisions. It is also recently that historians are investigating the war's societal meaning. Interestingly, comparative studies of European civil war in this era ignore the Irish civil war entirely (Diner 2008, Traverso 2016; Payne 2012). Some, citing the lack of massive violence against civilians, stress its uniqueness (Rodrigo 2017). The Catholic basis of the inter-class community and the weakness of the left makes the Irish case seem exceptional.

\section{Why Finland?}

Why did the Finnish civil war become a cultural trauma, whereas the Irish conflict never became a dominant referent in terms of national identity? Differing levels of violence provide one explanation: 35,000 deaths dwarf the less than 1,500 fatalities in Ireland. Almost two thousand people died in the battle for the 
industrial town of Tampere, (fought between 22 March and April 6 1918), more than in the entire Irish civil war. In 1998 a state-sponsored project was begun in Finland which tried to identify as many as 40,000 people who lost their lives between 1914 and 1922. Most (nearly thirty five thousand) were killed in the civil war (Alapuro 2002: 180). In Ireland, in 1986 a National Day of Commemoration was inaugurated by the state, to commemorate all those who died fighting in wars in the twentieth century, including soldiers fighting for the British Army. A small minority of the lives lost were due to the civil war.

Secondly, the Finnish conflict was exceptional in the context of Finnish history. Stenius (2012: 224-225) suggests that the inability to find consensus on the naming of the Finnish civil war was due to its more 'irreconcilable' nature than in Ireland, where the civil war was not the greatest tragedy. Before 1914 there had been no Finnish tradition of political violence and the Finns were law-abiding subjects of the Russian Empire. The violence could not easily be incorporated into national traditions. The Finns had never revolted 
against the Tsar (or the Swedes), and before Russification nationalists did not usually accept analogies with the more radical (and Catholic) Irish nationalists (Newby 2017: 180).

In Ireland divisions between constitutional and militant nationalists were not new in 1922. A huge cottage industry grew around creating biographies of the rival nationalist leaders, Eamon de Valera and Michael Collins, who embodied the fusion of constitutional and militant tendencies. Today the civil war is generally narrated, not as an exceptional event, but as the tragic denouement of the War of Independence. Two recent Hollywood films Michael Collins, and The Wind that Shakes the Barley begin with the War against the British (1916-1921) and end with the tragedy of civil war. Most contemporary histories share this chronology.

Thirdly, the fact that many Finns seemed supportive of socialism in 1917 meant that their revolution was harder to absorb into existing conceptions of the nation. Given the proximity of the Soviet Union it was an 'Incomprehensible' revolutionary attempt (Alapuro 2014: 19-22). For the names used for the civil war, the 
Social Democrats' preference was for 'kansalaissota' (peoples' war) while the communists preferred 'luokkasota' (class war). The neutral term 'sissällisota', preferred by some Social Democrats, translates as 'internal war' (Alapuro 2002: 172). All are societal categories. It is as if the Finnish conflict released a stronger symbolic charge into society because it was a social conflict (ibid: 17). Its social roots had been evident before 1918, when the politics of agrarian agitation was much more influenced by socialist ideas than in Ireland (Suodenjoki 2017). The Irish were initially more interested in nationalist narratives. P. S. O'Hegarty's pro-treatyite (1924) The Victory of Sinn Féin and MacArdle's (1937) republican The Irish Revolution, both presented the civil war as an episode in the move toward independence. Two histories in the 1960s (Neeson 1966; Younger 1965) continued the pattern. It is fair to say that this remains a submerged conflict. Situated between the two struggles against British rule (1916-1923 and 1969-1998) it is under-researched and a societal reading of what happened is harder to advance. 
The concept of a cultural trauma consists of an emotional experience and an interpretive reaction. On the one hand, the Red and White terrors placed a greater burden on memory. Yet neither did the Finns have the interpretative tools to come to terms with this violence. For Eyal (2004: 10-11) trauma stands for psychological pain so powerful, .... that it becomes impossible to localise in a sequence of events. Real trauma questions the linear and progressive temporality of the nation in a way that did not happen in Ireland. We normally ask of traumatic violent events whether they are characterized by a certain 'non-assimilability': by the enormous difficulty for the sufferer to integrate them into the framework of interpretation at their disposal (Joas 2005: 368). By most standards the Irish conflict was more 'assimilable'. Had the Irish Free State executed, not 81 , but more than 10,000 IRA men, while another 10,000 died in camps, the state's subsequent approach to the past would have been different. In Finland the amount of blood spilt by the Whites was never going to be forgotten. 


\section{Memory and Reconciliation.}

The process of coming to terms with the Finnish civil war reflects the workings of 'cultural memory' and was part of the search for unity under the Russian threat, a quest which had been violently interrupted in 1918 but carried on after 1944. Finnish changes in attitudes towards the civil war are also consistent with the view that shifts in cultural memory take time and come from below (Sierp 2014: 10-12). Sundholm (2011) says that no meanings are inherent in the event, but says of Finland in 1918 that some events are so horrible that it takes an extensive time-span to appropriate them. And one reason the integration of the left required cultural work was that the Finnish working class -with its own educational, sporting and welfare institutions - was culturally isolated after the civil war. In a society with deep social segregation theirs had been a case of 'negative integration', symbolised by the Social Democrat Premier Tanner taking the salute as Prime Minister at a commemoration of the White Victory in 1927 (Kirby 1979: 96). In contrast, de Valera was enabled by his electoral success to introduce a 
new constitution in 1937 symbolizing a rejection of the Treaty settlement.

Ireland in contrast, provides a good example of the construction (from above) of political memory, a type of memory tied, not so much to trauma, but to ongoing political projects (Sierp 2014: 11). Of the three first civil war histories, one author (Dorothy MacArdle) was personally close to de Valera, another (P.S. O' Hegarty) was a prominent pro-treatyite who became a senior civil servant, while William O' Brien, was a famous nationalist politician who interviewed de Valera during the civil war. $^{1}$ This political memory has nonetheless been very stable, one reason being that Fianna Fáil: the Republican Party has long competed electorally with Fine Gael: the United Ireland Party.

In what sense did the Finnish conflict become a unifying cultural trauma? There was a discernible improvement in the relations of parties formerly in conflict. And this improvement

\footnotetext{
${ }^{1}$ O'Brien's The Irish Free State: a secret history of its foundation' was never published. It is held in the National Library of Ireland, Ms 4210.
} 
was the result of satisfactorily dealing with the legacies of the past (Radzick and Murphy 2015). Yet reconciliation did still not result in an agreed interpretation of the civil war. The Mannherheim Museum in Helsinki still refers to the civil war as a liberation war. Finland had stabilized in the 1920s and 1930s by establishing two 'blocs' which institutionalized civil war differences at the heart of political life. Truth was not necessary for this process, and Finland became 'a land of two historical truths' as a result (Haapala 2008). In 2016 the Finnish broadcaster Yle carried out a survey of 400 Finns on their attitudes towards the civil war; memories remained sharp and divided, even within families (Uutiset 15 May 2016).

In this context reconciliation meant only an acceptance that rival perspectives on the civil war were legitimate and the creation of an interpretive space in which they could co-exist. These perspectives brought historical 'clarity' more than 'truth' to the past. Alapuro has commented that so complex was the Finnish civil war that any conceptualization of it is likely to be partisan. $^{2}$

\footnotetext{
2 'Interpretation of the Finnish Civil War of 1918', https://vimeo.com/30476075.
} 
His comment raises the philosophical question of whether complexity is a reflection of the event itself, or of the way it becomes assimilated into historical memory over time. Either way, when explaining such wars, 'perspective' and 'knowledge' become almost identical terms (Ortega y Gasset 1967: 44).

The approach most conducive to national reconciliation was not the positivist one of establishing which set of propositions about 1918 were factually correct. Rather knowledge consisted in the continual search for better interpretations. Coming to terms with a civil war past consisted rather of a hermeneutic broadening of the known context so that a fuller understanding was reached (Cohn 2002: 49). What gets in the way of this process is any narrowing of the context to the civil war so that one interpretation emerges as the truth. And each generation is entitled to its own interpretation.

Will the Irish state adopt this approach when it commemorates the hundredth anniversary of its civil war in 2022? In an implicit reference to the civil war, current President Michael 
D. Higgins has called for an 'ethics of memory', enabling 'different versions of the same events to be placed side by side, uncomfortable truths to be acknowledged'. ${ }^{3}$ As it stands, the civil war remains submerged in cultural memory between the earlier War of Independence and the later Northern Ireland Troubles. The latter conflict has helped 'shut down' discussion of the Civil War of 192223 in a state many of whose problems had been set by earlier acts of violence (Keane 2017: 16). And it has been difficult for historians to consider the legacy of earlier conflicts without being influenced by the Northern conflict (Regan 2013). The societal meaning of 19201923 remains obscured by the pivotal role the civil war played in southern Irish state and nation-building.

For Newman (2015: 9) the societal meaning of a civil war may also reflect its place in a larger cycle of conflicts. The first step in terms of broadening perspectives on the Irish civil war is to clarify its relationship with the earlier War of Independence, (1919-1921), the contemporaneous violence in Northern Ireland (1920-1922) and

\footnotetext{
${ }_{3}^{3}$ Acceptance speech on being re-elected President, Dublin Castle, 28/10/2018, RTE News.
} 
the later Northern Irish troubles (1969-1998). If the earlier conflict was a larger Irish civil war (1913-1923), the narrative of an uplifting war of national liberation after the 1916 Rising is hard to sustain. If the violence which took place in Northern Ireland after partition in 1920 was part of 'the Irish civil war', the legitimacy of the Irish Free State becomes less central to the analysis. And if the Northern Troubles were a sign that the IRA had not accepted its defeat in 192223, the Irish civil war did not end in 1923.

These issues show the civil war burdening memory in a very political way. And the northern Irish peace process has brought Sinn Féin back into the competition over the past. When in 2016 the Irish state staged its commemoration of the 1916 Easter Rising Sinn Féin organized its own events as it had done since 1923. The committee of historians appointed to advise the government on the current 'decade of commemorations' commented that the state should not be expected to be neutral about its own origins. ${ }^{4}$ So while

\footnotetext{
4 'Initial Statement by Advisory Group on Centenary Commemorations', www.//decadeofcentenaries.com
} 
Irish political memory has long been more attuned to politics, commemoration could reproduce the trauma of state formation.

The civil war did not crystallize much that was new about Irish national identity: it revealed more about the capacity for statehood. On the one hand, a stable democracy was constructed. Yet this achievement 'was based on a decision not to settle accounts' (Walsh 2015: 427). Journalist Justine McCarthy (Times on Sunday 2017) argues that if the Irish state was a person it would be a psychological head-wreck, unable to get a handle on its own identity because it has spent its entire existence in denial about its origins. Two days before the 1932 changeover, the Minister of Defense, Desmond FitzGerald, instructed his civil servants to destroy sensitive material relating to the state's 81 civil war executions. Not a single academic article has yet been published about them.

A common European response to the experience of civil war has been for a 'thin' political accommodation to take place first; a 'thick' reconciliation- involving truth and justice- takes more time. This was also the Finnish sequence. The non-emergence of a 
cultural trauma in Ireland could be taken to be a proxy for avoiding issues which the political elite finds inconvenient. The path to peace - political accommodation of the losers without a thick reconciliation involving truth and justice - goes against the tenets of the transitional justice literature. In this sense it is the Irish, not the Finnish case which is exceptional. Yet perhaps the transitional justice literature, which stresses the benefits to society of openly dealing with the past it too universal in application. Its' 'politics of time' is future-oriented, and mechanisms such as truth commissions are intended to mark a break with the past (Bevernage 2010: 113). Yet a society which conceives itself as continuous in time may have to change its identity in order to openly account for the past. Such a change will be resisted (Vernon 2012: 88-111). For whatever political motives Irish elites have had in constructing memories of the civil war they clearly have not been able to 'write the past out of the present' (ibid).

\section{Conclusion}


This article began with the reflection that there is little work on the role of national identity in post-civil war reconstruction and reconciliation, a judgement that does not apply to work on ethnic conflict. It posed the question of whether re-integration was possible on the basis of an existing national identity. In Finland and Ireland it was, and the political re-integration of the losers happened relatively quickly. When we consider the question of what has to happen to make that identity more inclusive, I have highlighted the role of narration in historicizing the Irish civil war and in bringing cultural repair to the class divisions of Finland.

These countries responded to the trauma of civil war in different ways. In explaining the contrast, the civil war experiences provide the independent variable; the subsequent emergence (or not) of cultural trauma is the outcome that needs explanation. Both conflicts could have suggested that the nation-state was not the end-point of nationalism. Yet the Irish were able to localise what happened in a sequence of developments: for both sides 1922 was part of the story of an unfinished nationalist 
revolution. With its greater violence, class hatred, and deadly prison camps the Finnish civil war marked more a fissure in the chain of events and needed rethinking. Hence the cultural trauma which followed.

The novelist Karen Blixen (1957) once remarked that 'all sorrows can be borne if you put them into a story or tell a story about them'. Her comment gets to the essential difference between the two cases, and can be understood in terms of the continuing hegemony of nationalist storytelling in Ireland. The stories about the revolutionary past constitute a 'transmissible' experience, in the sense of the Irish revolution being a founding experience for the traditions of a Catholic community that is still able to find in the struggles of the past the materials that weave together the elements of its present existence (Benjamin 1970: 1999). Protestants, north and south, remained outside this narrative. In contrast, the Finnish civil war was not transmissible: being a shock to the dominant conceptions of nationhood, it left the defeated side outside the national story for half a century. Hence 
the longer and more difficult challenge of absorbing the conflict into Finnish national identity.

Bibliography.

Alapuro, Riots. 1988. State and Revolution in Finland, Berkley: University of California Press.

Alapuro, Risto. 2002. 'Coping with the Civil War of 1918 in Twenty-First Century Finland' in K. Christie and R. Cribb (eds.), Historical Injustice and Democratic Transition in Eastern Asia and Northern Europe. 169-184. London and New York: Routledge.

Alapuro, Risto. 2014. 'The Legacy of the Civil War of 1918 in Finland', in B. Kissane (ed.) After Civil War: Division, Reconstruction and Reconciliation in Contemporary Europe, 17-43. Philadelphia: University of Pennsylvania Press. Alexander, Jeffrey. 2004. 'Toward a theory of cultural trauma' in J. Alexander, R. Eyerman, B. Giesen, N. J. Smelser, and P. Sztompka 9eds.) Cultural Trauma and Collective Identity. 1-31. Berkley: University of California Press.

Ankersmit, Frank. 2002. Political Representation. Stanford: Stanford University Press.

Armitage, David. 2017. Civil War: A History in Ideas. New York: Alfred A. Knopf. 
Benjamin, Walter. 'The Story-Teller: Reflections on the Work of Nikolai Leskov'. Illuminations. London: Pimlico 1999, pp.83-108.

Bevernage, Berber, 'Writing the Past Out of the Present: History and the Politics of Time in Transitional Justice, History Workshop Journal, 69:111-131.

Blixen, Karen. 1957. 'Interview with Bent Mohn', New York Times Book Review 3 November.

Bollas, Christopher. 2016. When the Sun Bursts; the Enigma of Schizophrenia. Yale: Yale University Press.

Bowyer Bell , J. 1972. 'Societal Patterns and Lessons: The Irish Case', in R. Higham (eds.), Civil Wars in the Twentieth Century, 217-228. Lexington: University of Kentucky Press.

Bracher, Karl Dietrich, 1985. The Age of Ideology: A History of Political Thought in the Twentieth Century. London: Methuen \& Co.

Centeno, Miguel A. 2002. Blood and Debt: War and the Nation State in Latin America. Pennsylvania: Pennsylvania University Press.

Clark, Gemma. 2014. Everyday Violence in the Irish Civil War. Cambridge: Cambridge University Press.

Cohn, Hans W. 2002. Heidegger and the Roots of Existential Therapy. London and New York: Continuum. 
Collier, Paul, Elliot V.L., Havard Hegre, Anke Hoeffler, Marta Reynal-Queral, and Nicholas Sambanis (eds.) 2013. Breaking the Conflict Trap: Civil War and Development Policy. Washington D.C.: Oxford University Press.

Curran, Joseph M. 1986. The Birth of the Irish Free State 1921-1923. Alabama: University of Alabama Press.

Daly, Mary E. 1992. Industrial Development and National Identity 1922-1939. Dublin.

Diner, Dan. 2008. Cataclysms: A History of the Twentieth Century from Europe's Edge. University of Wisconsin Press.

Dolan, Anne. 2003. Commemorating the Irish Civil War: History and Memory. Cambridge: Cambridge University Press.

Eyal, Gil. 2004. 'Identity and Trauma: Two Forms of the Will to Memory', History and Memory 16, 1: 5-36.

Eyerman, Ron. 2001. Cultural Trauma: Slavery and the Formation of the African American Identity. Cambridge: Cambridge University Press.

Eyerman,Ron. 2012. 'Cultural Trauma: Emotion and Narration' in J. Alexander, R.N. Jacobs and P. Samuel (eds.), The Oxford Handbook of Cultural Sociology, 564-583. Oxford: Oxford University Press.

Flanagan, Frances. 2015. Remembering the Revolution: dissent, culture and nationalism in the Irish Free State. Oxford: Oxford University Press. 
Forsberg, Tuomas, 2009. 'Post-Conflict Justice and the Finnish Civil War 1918. Reconciliation without Truth?', in J. Klabbers (ed.), Finnish Yearbook of International Law, vol. 18., 137-154, The Hague: Brill.

Foster, Gavin. 2014. The Irish Civil War and society: politics, class and conflict. Basingstoke:Palgrave MacMillan. 2014.

Gallagher, Frank. 1965 The Anglo-Irish Treaty. London: Hutchinson.

Garvin, Tom. 1981. The Evolution of Irish Nationalist Politics. Dublin: Gill and MacMillan.

Ghobarah, Hazem Adam, Paul Huth and Bruce Russett, 2003. 'Civil Wars Kill and Maim People: Long after the Shooting Stops', American Political Science Review 97, 2: 189-202.

González-Calleja, Eduardo. 2013. Las Guerres Civíles. Perspectivas de Analysis desde las Ciencias Sociales. Madrid: Catarata, 2013.

Greaves, Desmond C.. 1971. Liam Mellowes and the Irish Revolution. London: Lawrence and Wishart.

Haapala, Pertti. 2008. 'The Legacy of the Civil War 1918 in Finnish Historiography', Paper presented to the joint conference between Finnish and Estonian historians', The Difficult Past, No 2. 
Haapala, Pertti. 2012. 'The Expected and Non-expected Roots of Chaos: Preconditions of the Finnish Civil War', in T. Tepora and A. Roselius (eds.), The Finnish Civil War 1918: History, Memory, Legacy. 21-50. Leiden: Brill.

Hall John A. and Siniša Malešević. 2013. (eds.) Nationalism and War. Cambridge: Cambridge University Press.

Hall, John A. and John Cambell. 2017. The Paradox of Vulnerability: States, Nationalism and the Financial Crisis. Princeton: Princeton University Press.

Hämäläinen, Pekka, K. 1979. In Time of Storm: revolution, civil war, and the ethnolinguistic issue in Finland. Albany: University of New York Press.

Hopkinson, Michael. 1988. Green Against Green: the Irish Civil War. Dublin: Gill and MacMillan.

Hutchinson, John. 1987. The Dynamics of Cultural Nationalism: the Gaelic Revival and the Creation of the Irish Nation State. London: Routledge.

Hutchinson, John. 2005. Nations as Zones of Conflict. Sage: Beverly Hills.

Hutchinson, John. 2017. Nationalism and War. Oxford: Oxford University Press. Joas, Hans. 2005. 'Review Essay: Cultural Trauma? On the Most Recent Turn in Jeffrey Alexander's Cultural Sociology, European Journal of Social Theory 8, 3: 365-374. 
Jorstad, J. 1990. 'Nations Once Again: Ireland's Civil War in a European Context', in D. Fitzpatrick (ed.), Revolution? Ireland 1917-1923. Dublin: Trinity College,15973.

Karvonen, Lauri. 2000. 'Finland: From conflict to compromise', in D. Berg Schlosser and J. Mitchell (eds.), Conditions of democracy in Europe, 1919-39, 129157. Basingstoke: Macmillan.

Keane, Fergal. 2017. Wounds: A Memoir or War and Love. London. William Collins.

Kettunen, Pauli 2004. 'The Nordic Model and Consensual Competitiveness in Finland', in edited by A. Castrén, M. Lonkila and M. Peltonen (eds.), Between Sociology and History: Essays on Microhistory, Collective Action, and NationBuilding. 289-309. Helsinki: Finnish Literature Society.

Kirby, David. 1979. Finland in the Twentieth Century. London: Hurst \& Co.

Kissane, Bill. 2005. The Politics of the Irish Civil War. Oxford: Oxford University Press.

Kissane, Bill. 2014. (ed.) After Civil War: Division, Reconstruction and Reconciliation in Contemporary Europe. Philadelphia: Penn Press.

Kissane, Bill. 2016. Nations Torn Asunder: the Challenge of Civil War. Oxford: Oxford University Press.. 
Kostick, Conor. 1996. Revolution in Ireland: popular militancy, 1917 to 1923. London: Pluto Press.

Licklider, Roy. 1995. 'The Consequences of Negotiated Settlements in Civil Wars, 1945-1993. American Political Science Review 89, 3: pp.681-90.

Liikanen, Ilkka. 1995. Fennoman ja kansa. Joukkojarjestaytymsen lapimurto ja Suomalaisen puoleen synty. Hesinki: Suomen Historiallinen Seura. English summary.

Linna, Väinö. 2001. Under the Northern Star (trans. Richard Impola). Beavarton Ontario: Aspasia Books.

MacArdle, Dorothy. 1937. The Irish Republic: A Documentary Chronicle of the Anglo-Irish Conflict, with a detailed account of the period 1916-1923. London: Victor Gollanz.

Mazower, Mark. review of C, Pavone 'A Civil War: A History of the Italian Resistance'. Financial Times 22/11 13.

McCarthy, Justine. 'Let's look as Ireland's past, warts and all', Times on Sunday, 6 August 2017.

McMahon, Richard and Andrew G. Newby, 2017. 'Ireland and Finland, 18601930: Comparative and Transnational Histories', Irish Historical Studies 41, 160:166-179. 
Mikkala, Pirjo. 2012. 'Finland: Carving an Identity from Struggle' in P. Furtado (ed.), Histories of Nations: How their Identities were Forged, London: Thames and Hudson.

Neeson, Eoin. 1966. The Civil War in Ireland. Cork: Mercier Press.

Nevavkivi, Jukka, Jussila Osmo and Seppo Hentilä., 1999. From Grand Duchy to a Modern State: A Political History of Finland Since 1809. London: Hurst \& Co.

Newby, Andrew. 2017. 'Black Spots on the map of Europe: Ireland and Finland as oppressed nationalities, c1860-1910', (McMahon and Newby (eds.) 'Ireland and Finland, 1860-1930: Comparative and Transnational Histories'), Irish Historical Studies 41,160: 180-199.

Newman, Edward. 2014. Understanding Civil War: Continuity and Change in Intrastate Conflict. London: Routledge.

O' Halpin, Eunan. 1999. Defending Ireland: the Irish State and its Enemies since 1922. Oxford: Oxford University Press.

Ortega Y Gasset, José. 1967. The Origin of Philosophy. New York: Norton.

Payne, Stanley, 2012. Civil War in Europe, 1905-1945. Cambridge: Cambridge University Press.

Pavoni, Caesar. 2013. A Civil War: A History of the Italian Resistance. London: Verso. 
Peltonen, Matti. 1995. 'From peasant holdings to family farms', in L. Graberg and J. Nikula (eds.), The Peasant State; the state and rural questions in twentieth century Finland. 23-42. Rouvaniemi: University of Lapland Press.

O' Callaghan, Margaret. 1984. 'Language, Nationality and Cultural Identity in the Irish Free State, 1922-7: The "Irish Statesman" and Catholic Bulletin reappraised', Irish Historical Studies 94, 24: 226-245.

Peltonen, Ulla-Maija. 2002. 'Civil War Victims and Mourning in Finland in 1918' in K. Christie and R. Cribb (eds.), Historical Injustice and Democratic Transition in Eastern Asia and Northern Europe, 184-197. London and New York: Routledge.

Radzik, Linda and Murphy, Colleen, "Reconciliation", The Stanford Encyclopedia of Philosophy (Summer 2015 Edition), Edward N. Zalta (ed.), URL $=<$ https://plato.stanford.edu/archives/sum2015/entries/reconciliation/>.

Regan, John M. 2013. Myth and the Irish State: Historical Problems and Other Issues. Dublin: Irish Academic Press.

Rodrigo, Javier. 2017. 'Under the Sign of Mars: Violence in European Civil Wars, 1917-1949', Contemporary European History 26, 3: 487-506.

Schlink, Bernhard. 2010. Guilt about the Past. London: Beautiful Books.

Sierp, Aline. 2014. History, Memory and TransEuropean Identity: Unifying Divisions. New York: Routledge. 
Stenius, Henrik. 2012. 'Paradoxes of the Finnish Political Culture' in J. Páll Árnason and B. Wittrock (eds.), The Nordic Path to Modernity, 207-228. New York Oxford: Berhgahn Books.

Sundholm, John. 2011. 'The Cultural Trauma Process and the Ethics and Mobility of Memory', in J. Creet and A. Kitzmann (eds.), Migrating Memory: Multidisciplinary Approaches to Memory Studies. 120-134. Toronto: University of Toronto Press.

Smelsner, Neil. 2004. 'Psychological Trauma and Cultural Trauma', in J. Alexander, R. Eyerman, B. Giesen, N. J. Smelser, and P. Sztompka (eds.), Cultural Trauma and Collective Identity. 31-59. Berkley: University of California Press.

Suodenjoki, Sami, 2017. 'Mobilising for land, nation and class interests: agrarian agitation in Finland and Ireland, 1879-1018, (McMahon and Newby (eds.)'Ireland and Finland, 1860-1930: Comparative and Transnational Histories'), Irish Historical Studies 41, 160: 200-220.

Sztompka, Piotr. 2000. 'Cultural Trauma: The Other Face of Social Change', European Journal of Social Theory 3, 4: 449-466.

Tepora, Tuomas, 2014. 'Coming to Terms with Violence: Sacrifice, collective memory and reconciliation in inter-war Finland', Scandinavian Journal of History 39, 4, pp.487-509. 
Tilly, Charles. 1975. The Formation of National States in Western Europe. Princeton: Princeton University Press.

Traverso, Enzo. 2016. Fire and Blood: the European Civil War (1914-1945), (trans. David Fernbach. London: Verso.

Younger, Carlton. 1965. Ireland's Civil War. London: Fontana.

Vernon, Richard. 2012. Historical Redress: must we pay for the past? New York and London: Continuum.

Walsh, Maurice, 2015. Bitter Freedom: Ireland in a Revolutionary World. London: Faber.

Woods, Eric Taylor and Mira Debs. 2013. 'Towards a cultural sociology of nations and nationalism', Nations and Nationalism 19, 4: 607-614.

Wimmer, Andreas. 2012. Waves of War: Nationalism, State Formation and Ethnic Exclusion in the Modern World. Cambridge: Cambridge University Press. 